\title{
Meat Quality in Katahdin Lamb Terminal Crosses Treated with Zilpaterol Hydrochloride
}

\author{
José A. Partida ${ }^{1}$, Tania A. Casaya ${ }^{2}$, María S. Rubio $^{2}$ \& Rubén D. Méndez ${ }^{2}$ \\ ${ }^{1}$ National Institute for Forestry, Agriculture and Livestock Research of México. México, D. F., México \\ ${ }^{2}$ Facultad de Medicina Veterinaria y Zootecnia, Universidad Nacional Autónoma de México. México, D. F., \\ México \\ Correspondence: José A. Partida, National Institute for Forestry, Agriculture and Livestock Research of México. \\ Progreso No. 5 Barrio de Santa Catarina Coyoacán, México, D. F., C. P. 04010 México. Tel: \\ 52-01-800-088-2222. E-mail: partida.jose@inifap.gob.mx
}

Received: September 7, 2015 Accepted: September 22, $2015 \quad$ Online Published: November 5, 2015

doi:10.5539/jfr.v4n6p48 URL: http://dx.doi.org/10.5539/jfr.v4n6p48

\begin{abstract}
The effect of Zilpaterol hydrochloride $(\mathrm{ZH})$ supplementation $(0$ vs. $0.15 \mathrm{mg} / \mathrm{kg}$ live weight) on the meat quality was evaluated in Katahdin x Charollais $(32 \mathrm{KCh})$ and Katahdin x Dorper $(28 \mathrm{KD})$ crosses. Lambs were fed a totally mixed ration with $14 \%$ crude protein $(\mathrm{CP})$ and $2.9 \mathrm{Mcal} \mathrm{EM} / \mathrm{kg}$ DM. Data were analyzed using a completely randomized 2 × 2 factorial design: 2 genotypes (KCh and KD) and $2 \mathrm{ZH}$ levels $(0$ and $0.15 \mathrm{mg} / \mathrm{kg}$ live weight). No interaction was found between $\mathrm{ZH}$ and the genotypes. The breed of the sire (BS) did not affect most of the meat traits, only $\mathrm{KCh}$ crosses had higher color values $\left(\mathrm{L}^{*}=34.0 \pm 0.6\right.$ vs. $35.6 \pm 0.6$; $\mathrm{a}^{*}=13.4 \pm 0.3$ vs. $14.9 \pm 0.4 ; \mathrm{b}^{*}=5.6 \pm 0.3$ vs. $6.6 \pm 0.4 ; \mathrm{h}^{*}=20.8 \pm 0.9$ vs. $23.0 \pm 0.09 ; \mathrm{C}^{*}=14.7 \pm 0.4$ vs. $\left.16.4 \pm 0.5\right)$, more fat $(11.2 \pm 0.5$ vs. $11.9 \pm 0.5)$ and less protein $(21.3 \pm 0.1$ vs. $21.8 \pm 0.0)$ than $\mathrm{KD}$. ZH meat had lower values $(\mathrm{P}<0.001)$ than meat from the control animals: $\mathrm{L}^{*}(31.9 \pm 0.6$ vs. $37.7 \pm 0.6)$, $\mathrm{a}^{*}(12.9 \pm 0.4$ vs. $15.5 \pm 0.4), \mathrm{h}^{*}(15.1 \pm 0.9$ vs. $28.6 \pm 0.9)$ and $\mathrm{C}^{*}(13.5 \pm 0.5$ vs. $17.7 \pm 0.8) . \mathrm{ZH}$ increased shear force on meat $(5.4 \pm 0.2 \mathrm{vs} .3 .7 \pm 0.2 \mathrm{kgf})$, and produced less fat (9.7 \pm 0.5 vs. $12.5 \pm 0.5 \%)$ and bone $(23.2 \pm 0.3$ vs. $24.6 \pm 0.2 \%)$, but more muscle $(65.8 \pm 0.5$ vs. $61.2 \pm 0.4 \%)$. Zilpaterol hydrochloride use in lamb production caused leaner yield and more protein retention, at the expense of reducing meat sensory qualities.
\end{abstract}

Keywords: Lamb, Meat quality, Sensory traits, Zilpaterol hydrochloride

\section{Introduction}

According to Food and Agriculture Organization (FAO, 2014), lamb production increased at an average rate of $1.12 \%$ per year during last decade. This moderate growth was due mainly to two factors, the first was the reduction of flocks in several countries caused by the presence of severe droughts in America, Australia, Africa and Middle East (Garniere, 2010); and the second, was the increase in grain prices caused by the use of maize for the biofuels industry (ICTSD, 2008). Nevertheless, for 2025 it is expected a growth of $2.5 \%$ annually in lamb production driven by a substantial lamb consumption increase in developing countries (OECD-FAO, 2013).

Mexico is not a highly lamb consumer (738 g / person / year) country (SAGARPA, 2005); however, to satisfy a demand for at least $750 \mathrm{~g}$ of lamb/person/year is necessary to import more than 31000 tons of sheep meat / year (SIAP, 2014). This situation provides an opportunity for Mexican sheep producers to increase their lamb production by more than $60 \%$ to meet current needs. During recent years, several specialized breeds in meat production had been introduced into the country to improve animal performance, carcass conformation and carcass finishing degree (Hernandez et al., 2009; Partida et al., 2009; Rios et al., 2011). Particularly, the crossing of hair ewes with males specialized in meat production, showed comparative advantages and generated different quality options to meet Mexican market demands (Bores et al., 2007; Rios et al., 2011; Vazquez et al., 2011). In some of these studies, Katahdin, Charollais and Dorper breeds were highlighted as the most efficient breeds in terms of growth and carcass traits (Bores et al., 2007; Macias et al., 2010; Vázquez et al., 2011; Partida et al., 2010). Beyond these improvements, the overall increase of slaughter weight ( $>45 \mathrm{~kg}$ ) has been considered a real possibility to reach the objective of increasing production. Literature indicates that an increase in slaughter weight is accompanied by an increase in the total fat quantity (Bianchi et al., 2006; Warris, 2003) and a reduction of body muscle proportion (Partida et al., 2011; Hopkins, 2005). Therefore, recent research has focused on 
evaluating various compounds that modify animal metabolism and improve lean carcass yield (Beermann, 2009; Dikeman, 2007; Sillence, 2004). Specifically, $\beta$-adrenergic agonists ( $\beta$-AA) increase protein synthesis and lipid degradation (Yang \& Mc Elligott, 1989; Mersman, 1998); however, studies in sheep have shown inconsistent results on body composition (Brand et al., 2013; Mondragon et al., 2010; Salinas et al., 2006). When we compared the results of recent studies that evaluated different $\beta$-AA (zilpaterol hydrochloride, ractopamina hydrochloride, terbutaline, metaprotenerol, isoprotenerol, BRL35135A, BRL26830, etc.) we found that zilpaterol hydrochloride was the best option for small ruminant (Mohammandi et al., 2006; Dickeman, 2007; Nourozi et al., 2008; López et al., 2010; López et al., 2011). In addition, Zilpaterol hydrochloride (Zilmax ${ }^{\circledR}$, Intervet México, México City), is a $\beta$-AA that produces extremely weak pharmacological actions in man, and are so rapidly metabolized and cleared from the animal's body, that it is virtually impossible to regard them as potential causes of drug poisoning in human beings, even after consuming meat products derived from animals medicated with these drugs (Sumano et al., 2002). Zilpaterol hydrochloride is a $\beta$-AA commercially available in México (Zilmax ${ }^{\circledR}$, Intervet México, México City), but registration and commercial use are approved in other 25 countries, such as the United States (NADA 141-258; FDA, 2006), Canada (Canadian Food Inspection), Brazil, Colombia, Peru, the Republic of South Africa South, Kazakhstan, Kore and others.

Nourozi et al. (2008) found agonists to have different effects depending on the type of adipose tissue. They reduce the amount of visceral fat (Samadi et al., 2013) and intramuscular fat (Mondragon et al., 2010), but do not affect subcutaneous fat (Yang and Mc Elligott, 1989; Coleman et al., 1988; Estrada et al., 2008). These effects on fat can modify meat taste and tenderness. Furthermore, $\beta$-AA also alter color, $\mathrm{pH}$ and texture (Davila et al., 2013; Mondragon et al., 2010; Salinas et al., 2006). All this indicates that use of $\beta$-AA on sheep production may substantially alter the organoleptic quality of meat. Given the above, the aim of this study was to evaluate the effect of the zilpaterol hydrochloride on meat quality in lambs from terminal crossbreeding of Katahdin females mated to males Charollais and Dorper.

\section{Materials and Methods}

\subsection{Animal Management and Experimental Design}

Lambs were raised in the municipality of Colón, Querétaro, located at $20^{\circ} 41^{\prime} 40.62^{\prime \prime}$ north latitude and $100^{\circ} 00^{\prime} 53.52^{\prime \prime}$ west longitude (Google, 2013). The weather in this region is mildly dry with an annual rainfall of $450 \mathrm{~mm}$ and a temperature range of $15-19^{\circ} \mathrm{C}$ (García, 1981). A 200-head Katahdin ewe flock of $51 \pm 18$ months of age and $6 \pm 2$ births was used for this study. Ewes were separated into 2 groups, synchronized using intravaginal progesterone sponges (Progestpon ${ }^{\circledR}$, Syntex, S. A., México) followed by an FSH application (Folligon ${ }^{\circledR}$, Merck, Sharp \& Dohme, México), and then inseminated (laparoscopy) using fresh semen from 5 unrelated Charollais (Ch) and 5 Dorper rams (D). A commercial diet (creep feeding) was given to the lambs from birth to weaning (78 \pm 6 days); after weaning, ram lambs were selected for further study and divided into 2 groups $(32 \mathrm{KCh}$ and $28 \mathrm{KD})$. Both groups went through a growing stage $(56 \pm 13$ days $)$ under similar management conditions, which included a totally mixed ration (sorghum $47.2 \%$, molasses $20.0 \%$, dry alfalfa $11.0 \%$, corn stover $8.0 \%$, canola $6.5 \%$, soybean paste $4.0 \%$, mineral and urea mix $3.3 \%$ ) with $14 \%$ crude protein (CP), $2.9 \mathrm{Mcal}$ of EM/kg MS and water ad libitum. The same mixed ration was used in the fattening stage, for both treatments, without ZH (control group) and with 6 ppm ZH (Zilmax ${ }^{\circledR}$, Intervet, S. A. de C. V., México; treated group: equivalent to $0.15 \mathrm{mg} / \mathrm{kg} \mathrm{LW} /$ day, approximately) for 30 days. The experimental groups were as follows: Group $1=14 \mathrm{KD}$ with $\mathrm{ZH}$; Group $2=14 \mathrm{KD}$ without $\mathrm{ZH}$; Group $3=16 \mathrm{KCh}$ with $\mathrm{ZH}$ and Group $4=$ $16 \mathrm{KCh}$ without $\mathrm{ZH}$. Work was done with the support of a cooperating producer under ordinary commercial conditions for sheep production. Following Intervet recommendations, ZH supplementation was withdrawn three days before slaughter. At the end of the fattening period, 10 animals from each group were randomly selected for slaughter. The lambs were slaughtered at Federal Inspection Type Facility No. 412 at San José El Alto, Querétaro, according to the industrial processes and procedures for animal welfare that have been established by federal authorities.

\subsection{Meat Instrumental and Sensory Evaluation}

After slaughter, hot carcasses were weighed and cooled at $4{ }^{\circ} \mathrm{C}$ for $24 \mathrm{~h}$. Then, carcasses were divided in two along the backbone. Later, the rack was removed from the left side cutting from the $4^{\text {th }}$ to the $12^{\text {th }}$ thoracic vertebra and measures were taken. Final $\mathrm{pH}_{24 \mathrm{~h}}$ was measured at the $12^{\text {th }}$ thoracic vertebra, using a portable pH-meter with a penetration probe (Hanna Instruments, HI-99163, Woonsocket, RI). The instrumental color (CIELAB) of the meat and fat (kidney fat) were measured using a Minolta CR-410 colorimeter (Konica Minolta Sensing, Inc., Osaka, Japan); the D65 illuminant was selected with an angle of $2^{\circ}$ and a 2 -cm measurement approach. In addition, Hue $\left(\mathrm{h}^{*}\right)$ and Chroma $\left(\mathrm{C}^{*}\right)$ were calculated. Before taking the measurements, meat 
samples were allowed to bloom for $1 \mathrm{~h}$ at $12 \pm 1{ }^{\circ} \mathrm{C}$. To determine meat composition (percentage of moisture, protein, intramuscular fat and ash) the $9^{\text {th }}$ or $10^{\text {th }}$ rib eye steak was extracted of the loin, and the official methods of analysis (AOAC, 2002) used. The left shoulder was separated from each carcass following the methodology of Vergara (2005). Shoulders were thawed for $24 \mathrm{~h}$ under refrigeration and weighed before being dissected (muscle, fat and bone) using Boccard methodology (1976). Waste (fascia, nerves tendons, vessels, etc.) was recorded with the bone. Indirect water holding capacity (water loss) was determined on the Longissimus dorsi muscle (MLD) by compression method and expressed as percentage of released juice (Pla, 2005). Briefly, a $0.30 \pm 0.05 \mathrm{~g}$ loin sample, between the $6-8^{\text {th }}$ rib, was placed on a No. 4 Whatman filter paper, previously weighed. The sample covered with glass was pressed under a $2.25 \mathrm{~kg}$ weight for $5 \mathrm{~min}$, afterwards the filter paper was weighed again and the percentage of juice loss from the sample was calculated based on weight difference (Pla, 2005). Shear force (SF) was determined according to Honikel (1998), but ageing period was only 24h. The MLD steaks were thawed for $24 \mathrm{~h}$ and cooked on a double plaque broiler to an internal temperature of $70{ }^{\circ} \mathrm{C}$, which was monitored with iron-constantan thermocouples (Omega Engineering Inc., Stamford, USA) and a recording portable thermometer. Upon reaching the desired internal temperature, steaks were removed from the broilers and allowed to cool to room temperature $\left(20-25{ }^{\circ} \mathrm{C}\right)$. Subsequently, from each steak, a minimum of six, $1.27-\mathrm{cm}$-diameter cores were obtained parallel to the longitudinal orientation of muscle fibers. Cores were cut perpendicularly using a texture analyzer TA. XT Plus (Stable Micro Systems). To quantify the texture of the raw meat, we measured stress of compression at $20 \%(\mathrm{C} 20)$ and at $80 \%(\mathrm{C} 80)$ of maximum compression $(\mathrm{N} / \mathrm{cm} 2)$ using a modified compression device that avoids transversal elongation of the sample (Lepetit \& Culioli, 1994).

\subsection{Sensory Evaluation}

The M. Longissimus lumborum was used for sensory evaluation. Each steak was thawed for $24 \mathrm{~h}$, wrapped in aluminum foil and cooked on a double plaque broiler until $70{ }^{\circ} \mathrm{C}$ was reached at the geometrical center. Upon reaching the desired internal temperature, muscles were removed from the broiler and portioned into cubes of uniform dimensions $\left(2 \mathrm{~cm}^{3}\right)$ and kept warm until evaluation. A consumer affective test was performed using a seven point hedonic scale from 1) I dislike it very much; to 7) I like it very much. In sample preparation and present samples to panelists, Campo (2005) methodology was used. A total of 60 panelists from different sex, age and cultural background participated in the study. Each panelist was presented four samples and asked to score each sample for flavor, tenderness, juiciness and overall desirability.

\subsection{Statistical Analysis}

Data were analyzed using a completely randomized 2 x 2 factorial design: 2 genotypes (KCh and $\mathrm{KD}$ ) and $2 \mathrm{ZH}$ levels $(0$ and $0.15 \mathrm{mg} / \mathrm{kg}$ ). The general lineal model procedure in SAS 9.1.3 (SAS, 2008) was used, and the separation of means was performed using Tukey's test. To eliminate the variability generated by secondary effects, such as birth type, maternal age, etc., the weight of the animals at the beginning of the finishing (ZH) period was used as a covariate (Steel \& Torrie, 1980). Water retention capacity (WRC) and chemical composition data were analyzed with the Cochran-Mantel-Haenszel test and meat $\mathrm{pH}$ were analyzed for normality using the Shapiro-Wilk test. Results from the sensory evaluation were analyzed by the Kruskal-Wallis test. All tests were performed at a $95 \%$ confidence level.

\section{Results and Discussion}

Two level interactions were not significant $(\mathrm{P}>0.05)$ for any of the studied traits, so results are presented for the main effects (sire breed and zilpaterol hydrochloride level). Table 1 shows effects of sire breed (SB) and zilpaterol hydrochloride $(\mathrm{ZH})$ on instrumental meat quality. The final $\mathrm{pH}$ was not affected by $\mathrm{SB}(\mathrm{P}=0.61)$ or by $\mathrm{ZH}$ supplementation $(\mathrm{P}=0.49)$. 
Table 1. Effects of sire breed and zilpaterol hydrochloride on instrumental meat quality (Mean $\pm \mathrm{EE}$ )

\begin{tabular}{|c|c|c|c|c|c|c|}
\hline \multirow{2}{*}{ Variable } & \multicolumn{3}{|c|}{ Sire breed } & \multicolumn{3}{|c|}{ Zilpaterol hydrochloride (mg/kg LW) } \\
\hline & Charollais & Dorper & $P$ value & 0 & 0.15 & $P$ value \\
\hline $\mathrm{pH} 24 \mathrm{~h}$ & $5.7 \pm 0.4$ & $5.7 \pm 0.5$ & 0.605 & $5.7 \pm 0.0$ & $5.7 \pm 0.5$ & 0.490 \\
\hline Water loss ${ }^{1}$ & $26.6 \pm 0.6$ & $28.1 \pm 0.7$ & 0.122 & $27.1 \pm 0.6$ & $27.6 \pm 0.7$ & 0.634 \\
\hline \multicolumn{7}{|l|}{ Meat Color } \\
\hline $\mathrm{L}^{*}$ & $34.0 \pm 0.6$ & $35.6 \pm 0.6$ & 0.024 & $37.7 \pm 0.6$ & $31.9 \pm 0.6$ & 0.001 \\
\hline$a^{*}$ & $13.4 \pm 0.3$ & $14.9 \pm 0.4$ & 0.007 & $15.5 \pm 0.4$ & $12.9 \pm 0.4$ & 0.001 \\
\hline$b^{*}$ & $5.6 \pm 0.3$ & $6.6 \pm 0.4$ & 0.001 & $3.7 \pm 0.4$ & $8.4 \pm 0.3$ & 0.435 \\
\hline $\mathrm{h}^{*}$ & $20.8 \pm 0.9$ & $23.0 \pm 0.9$ & 0.019 & $28.6 \pm 0.9$ & $15.1 \pm 0.9$ & 0.001 \\
\hline $\mathrm{C}^{*}$ & $14.7 \pm 0.4$ & $16.4 \pm 0.5$ & 0.004 & $17.7 \pm 0.8$ & $13.5 \pm 0.5$ & 0.001 \\
\hline \multicolumn{7}{|l|}{ Texture: } \\
\hline Shear force (kgf) & $4.9 \pm 0.2$ & $4.3 \pm 0.2$ & 0.068 & $3.7 \pm 0.2$ & $5.4 \pm 0.2$ & 0.001 \\
\hline Compression $20 \%\left(\mathrm{~N} / \mathrm{cm}^{2}\right)$ & $5.6 \pm 0.2$ & $5.8 \pm 0.2$ & 0.390 & $5.6 \pm 0.2$ & $5.7 \pm 0.9$ & 0.218 \\
\hline Compression $80 \%\left(\mathrm{~N} / \mathrm{cm}^{2}\right)$ & $21.8 \pm 0.7$ & $23.1 \pm 0.8$ & 1.460 & $22.4 \pm 0.7$ & $22.5 \pm 0.6$ & 1.480 \\
\hline Total load $(\mathrm{N})$ & $27.3 \pm 0.8$ & $28.8 \pm 0.9$ & 1.408 & $28.1 \pm 0.9$ & $28.1 \pm 0.9$ & 0.100 \\
\hline
\end{tabular}

There was not effect of genetic group $(\mathrm{P}>0.05)$ or $\mathrm{ZH}$ in water loss $(\mathrm{WL})$ averaging $27.4 \pm 0.7 \%$ of expelled juice. Water loss is a variable associated to meat juiciness and values between $25-35 \%$ are consistent with previous results (Partida et al., 2012) and they point out juicy meat. These results are consistent with those of studies that evaluated two $\beta$-AA on finishing lambs where not significant effects were observed on $\mathrm{pH}$, hold water capacity and water loss (Brand et al., 2013; López et al., 2010). However, present results contrast partially with those of Dávila et al, (2013) that showed pH values of 6.2 in hair lamb treated with $\mathrm{ZH}$, which is a value that would correspond to a dry, firm and dark meat (Vergara, 2005). Other studies showed that $\beta$-AA administration reduces $\mathrm{pH}$ drop after slaughter due to anabolic metabolism (Gregory, 1998; Moloney \& Beermann, 1996).

Meat color was affected by SB and ZH $(\mathrm{P}<0.05)$. KD had slightly higher $(\mathrm{P}<0.024)$ lightness $\left(\mathrm{L}^{*}\right)$, redness $\left(a^{*}\right)$, yellowness $\left(b^{*}\right)$, hue $\left(h^{*}\right)$ and Chroma $\left(\mathrm{C}^{*}\right)$ values than KCh. On the other hand, ZH meat had lower $(\mathrm{P}<$ $0.001) \mathrm{L}^{*}, \mathrm{a}^{*}, \mathrm{~h}^{*}$ and $\mathrm{C}^{*}$ values than meat from the control animals. Literature review indicates that the effect of $\mathrm{ZH}$ on meat color has not been consistently shown. Different factors contribute to this inconsistency, such as final pH and temperature (Sañudo et al., 1989), lower concentration of heme pigment (Ferreira \& Bastos, 1994; Warris et al., 1990), small quantity of oxy-myoglobin (Ramos \& Silveira, 2002). Some studies using sheep have found no effect of ZH on color variables (Avendaño et al., 2006; Romero, 2011; Berge et al., 1990), but results from Dávila et al. (2013) were similar to those of the present study. A possible explanation for the reduced lightness in the meat of ZH-treated sheep is the reduction in the amount of intramuscular fat (marbling), which is white in animals finished with high in energy rations (Wulf \& Wide, 1999).

No differences $(\mathrm{P}>0.05)$ due to SB or ZH administration were observed in any compression parameters. Shear force (SF) was not affected by SB (P $>0.05)$, but $\mathrm{ZH}$ produced meat $46 \%$ hardest than the control treatment $(\mathrm{P}=$ 0.001), which agrees with tenderness data from the sensory evaluation (see below). The decrease in meat tenderness in animals treated with $\mathrm{ZH}$ has also been observed by other researchers (Kim et al., 1987; Koohmaraie et al., 1996; Ketchmar et al., 1987; Davila et al., 2013; Mondragón et al., 2010). Meat softness is the most important organoleptic property for consumers (Koohmaraie, 1994) and a value around $3.7 \mathrm{kgf}$ is considered very soft meat, while $5.4 \mathrm{kgf}$ correspond to hard meat (Wheeler et al., 1997). According to literature, in meat that not have been aged for more than $24 \mathrm{~h}$, the $\mathrm{ZH}$ effect on the meat hardness could be explained by different factors such as: intramuscular fat decrease (Holmer et al., 2009; Mondragón et al., 2010), increase in the muscle fibers diameter (Buttery et al., 2000), increase in amount of connective tissue and the number of fast twitch fibers type II (Maloney \& Allen, 1996).

Table 2 shows effect of SB and ZH on shoulder tissue composition. Sire breed did not affect $(\mathrm{P}>0.05)$ fat, bone 
and muscle percentages, but $\mathrm{ZH}$ administration produced $22.4 \%$ less fat $(\mathrm{P}<0.001), 5.7 \%$ less bone $(\mathrm{P}<0.004)$ and $7.5 \%(\mathrm{P}<0.001)$ more muscle in the shoulder than the control ones.

Table 2. Effects of sire breed and zilpaterol hydrochloride on shoulder tissue composition (\%) on lamb (Mean \pm $\mathrm{SE})$

\begin{tabular}{|c|c|c|c|c|c|c|}
\hline \multirow{2}{*}{ Variable } & \multicolumn{3}{|c|}{ Sire breed } & \multicolumn{3}{|c|}{$\begin{array}{l}\text { Zilpaterol hydrochloride } \\
(\mathrm{mg} / \mathrm{kg} \mathrm{LW})\end{array}$} \\
\hline & Charollais & Dorper & $\begin{array}{c}\mathrm{P} \\
\text { value }\end{array}$ & 0 & 0.15 & $\begin{array}{c}\mathrm{P} \\
\text { value }\end{array}$ \\
\hline Fat & $11.2 \pm 0.5$ & $11.9 \pm 0.5$ & 0.968 & $12.5 \pm 0.5$ & $9.7 \pm 0.5$ & 0.001 \\
\hline Bone & $23.8 \pm 0.3$ & $24.0 \pm 03$ & 0.307 & $24.6 \pm 0.2$ & $23.2 \pm 0.3$ & 0.004 \\
\hline Muscle & $63.4 \pm 0.4$ & $63.7 \pm 0.5$ & 0.752 & $61.2 \pm 0.4$ & $65.8 \pm 0.5$ & 0.001 \\
\hline \multicolumn{7}{|l|}{ Ratio: } \\
\hline Muscle : fat & $5.7 \pm 0.2$ & $5.4 \pm 0.1$ & 0.860 & $4.9 \pm 0.1$ & $6.8 \pm 0.2$ & 0.001 \\
\hline Muscle : bone & $2.7 \pm 0.1$ & $2.7 \pm 0.0$ & 0.530 & $2.5 \pm 0.1$ & $2.8 \pm 0.1$ & 0.010 \\
\hline
\end{tabular}

2-way interactions were not significant $(\mathrm{P}>0.05)$ for any traits.

These data originated better ratios $(\mathrm{P}<0.01)$ muscle/fat $(4.9$ vs 6.8$)$ and muscle/bond $(2.5$ vs 2.8$)$ for $\mathrm{ZH}$ treated animals. Shoulder tissue composition is highly correlated to body composition ( $\%$ muscle $r^{2}=0.97 ; \%$ fat $r^{2}=$ 0.95 ; \% bone $r^{2}=0.73$ ) (Vergara, 2005), so ZH supplementation increased the final amount of shoulder meat by $0.240 \mathrm{~kg}$, which is equivalent to $1.6 \mathrm{~kg}$ of additional marketable meat. The effect of $\mathrm{ZH}$ on carcass composition has been widely reported on sheep (Salinas et al., 2004; Salinas et al., 2006; Estrada et al., 2008; López et al., 2010; López et al., 2011; Mondragón et al., 2010) and it is agreed on the decrease in amount of fat and the increase on the proportion of muscle by the $\mathrm{CZ}$ effect, which can be explained by the cell metabolism modification, favoring protein synthesis and fat degradation (Mersmann 1998; Li et al., 2000). Additional protein, formed with energy derived from lipid catabolism, is deposited within the cells originating muscle hypertrophy (Kim et al., 1987; Maloney et al., 1990). However, every muscle responds according to type and proportion of muscle fibers, being more evident the hypertrophy in type II fast contracting fibers (Bermann, 2002).

$\mathrm{SB}$ and $\mathrm{ZH}$ affected meat composition (Table 3). Meat from Charollais breeds had slightly more fat (2.8 vs. $2.0 \%)$ and less protein (21.3 vs. 21.8\%) than Dorper. Also, $\mathrm{ZH}$ meat had $40.0 \%$ less fat $(\mathrm{P}<0.004)$ and $12.0 \%$ more protein $(\mathrm{P}<0.001)$ than control meat. Differences in meat composition between breeds may be due to differences in degree of maturity of each breed (Warris, 2003); in the present study, Charollais reached maturity faster than Dorper animals. Boler et al. (2009) and Ferguson (2001) reported more moisture and less fat in carcass originated from $\mathrm{ZH}$ treated animals.

Table 3. Effects of sire breed and zilpaterol hydrochloride on meat chemical composition (\%) on lamb (Mean \pm EE)

\begin{tabular}{|c|c|c|c|c|c|c|}
\hline \multirow{2}{*}{$\begin{array}{l}\text { Variable } \\
\%\end{array}$} & \multicolumn{3}{|c|}{ Sire breed } & \multicolumn{3}{|c|}{$\begin{array}{l}\text { Zilpaterol hydrochloride } \\
\text { (mg/kg LW) }\end{array}$} \\
\hline & Charollais & Dorper & $P$ value & 0 & 0.15 & $P$ value \\
\hline Moisture & $74.0 \pm 0.2$ & $74.3 \pm 0.2$ & 0.316 & $73.9 \pm 0.2$ & $74.3 \pm 0.2$ & 0.137 \\
\hline Protein & $21.3 \pm 0.1$ & $21.8 \pm 0.1$ & 0.004 & $20.8 \pm 0.1$ & $22.3 \pm 0.1$ & 0.001 \\
\hline IM $^{1}$ Fat & $2.8 \pm 0.2$ & $2.0 \pm 0.2$ & 0.006 & $3.0 \pm 0.2$ & $1.8 \pm 0.2$ & 0.001 \\
\hline Ash & $1.1 \pm 0.1$ & $1.0 \pm 0.1$ & 0.459 & $1.0 \pm 0.0$ & $1.3 \pm 0.5$ & 0.104 \\
\hline
\end{tabular}

In general, consumer rated high (above average) meat in this study (Table 4). Sire breed did not affect meat sensory properties $(\mathrm{P}>0.05)$. ZH meat had lower juiciness (5.2 vs. 4.7), softness (5.4 vs. 4.5), and overall likeness (5.3 vs. 4.9) values than the control treatment $(\mathrm{P}<0.01)$. In sheep, there are few and inconsistent studies 
evaluating the effect of $\mathrm{CZ}$ on the sensory characteristics of meat. Some researchers have observed $\mathrm{ZH}$ administration decreases softness, juiciness, flavor and overall likeness in sensory meat evaluation (Leheska et al., 2008; Hilton et al., 2014; Morón et al., 2002; Ramos and Silveira, 2002), while others have not observed significant differences in sensory data (Dávila et al., 2013; Mondragon et al., 2010; Schroeder, 2004). $\beta$-AA affect negatively the aging potential of meat because they increase activity of calpastatins (Hope-Jones et al., 2010) and/or decrease the amount of intramuscular fat (Dávila et al., 2013; Holmer et al., 2009; Mondragón et al., 2010).

Table 4. Effects of sire breed and zilpaterol hydrochloride on meat sensory quality on lamb (Mean $\pm \mathrm{EE}$ )

\begin{tabular}{|c|c|c|c|c|c|c|}
\hline \multirow{2}{*}{ Variable } & \multicolumn{2}{|c|}{ Sire breed } & \multicolumn{4}{|c|}{$\begin{array}{l}\text { Zilpaterol hydrochloride } \\
(\mathrm{mg} / \mathrm{kg} \mathrm{LW})\end{array}$} \\
\hline & Charollais & Dorper & $\begin{array}{c}P \\
\text { value }\end{array}$ & 0 & 0.15 & $\begin{array}{c}\mathrm{P} \\
\text { value }\end{array}$ \\
\hline Flavor & $4.9 \pm 0.1$ & $5.1 \pm 0.1$ & 0.392 & $5.1 \pm 0.1$ & $4.9 \pm 0.1$ & 0.098 \\
\hline Juiciness & $4.9 \pm 0.1$ & $5.0 \pm 0.1$ & 0.314 & $5.2 \pm 0.1$ & $4.7 \pm 0.1$ & 0.003 \\
\hline Softness & $4.8 \pm 0.1$ & $5.1 \pm 0.1$ & 0.118 & $5.4 \pm 0.1$ & $4.5 \pm 0.1$ & 0.001 \\
\hline Overall likeness & $5.0 \pm 0.1$ & $5.1 \pm 0.1$ & 0.725 & $5.3 \pm 0.1$ & $4.9 \pm 0.1$ & 0.004 \\
\hline
\end{tabular}

Hedonic scale considered 7 points: $1=\mathrm{I}$ dislike it very much; 7 = I like it very much. Sensory test involved 60 panelists, of whom $48.3 \%$ were men with an average age of 31 years (23-44 years) and the remaining 51.7\% were women with an age of 33 years in average (22-51 years).

\section{Conclusions}

The breed of the sire did not affect most of the meat traits, only Katahdin x Charollais crosses had lower meat color values, more fat and less protein than Katahdin x Dorper. Zilpaterol hydrochloride-treated animals had meat with less lightness, red color, hue and Chroma. Zilpaterol hydrochloride increased shear force on meat, and produced more muscle and less fat and bone. Zilpaterol hydrochloride use in lamb production caused leaner meat and more protein retention, at the expense of reducing meat sensory qualities.

\section{References}

Albertí, P., Panea, B., Ripoll, G., Sañudo, C., Olleta, J. L., Hegueruela, I., ... Serra, X. (2005). Medición del color. In: V. Cañeque \& C. Sañudo (Eds), Estandarización de las metodologías para evaluar la calidad del producto (animal vivo, canal, carne y grasa) en los rumiantes. (pp. 216-225). Madrid, España. Monografías INIA, Serie Ganadera No. 3.

Association of Official Analytical Chemists (AOAC). (2000). Official methods of analysis (17th ed.). Arlington, V. A. USA.

Avendaño, R. L., Torres, R. V., Meraz, M. F. J., Perez, L. C., Figueroa, S. F., \& Robinson, P. H. (2006). Effect of two b-adrenergic agonists on finishing performance, carcass characteristics and meat quality of feedlot steers. Journal of Animal Science, 84, 3259-3265. http://dx.doi.org/10.2527/jas.2006-173

Beermann, D. H. (2002) $\beta$-adrenergic receptor agonist modulation of skeletal muscle growth. Journal of Animal Science, 80(Suppl. 1), 18-23.

Beermann, D. H. (2009). ASAS Centennial Paper: A century of pioneers and progress in meat science in the United States leads to new frontiers. Journal of Animal Science, 87, 1192-1198. http://dx.doi.org/10.2527/jas.2008-1542

Berge, P. H., Culioli, J., Renerre, M., Lacourt, A., Renou, J. P., Ouali, A., ... Berry, M. (1990). Utilisation d' un $\beta$ - agoniste (clembuterol) pour la production de veau de boucherie: II - Influence sur la qualité de la viande. Viandes et Produits Carnés, 11, 235-236.

Bianchi, O. G., Gariboto, G., Feed, O., \& Franco, J. (2006). Efecto del peso al sacrificio sobre la calidad de la canal y de la carne de corderos Corriedale puros y cruza. Archivos de Medicina Veterinaria, 38(2), 161-165. http://dx.doi.org/10.4067/S0301-732X2006000200010

Boccard, R., Dumont, B. L., \& Lefebre, J. (1976). Etude de la production de la viande chez les ovins X. Rélations entre la composition anatomique des différentes régions corporelles de l'agneau. Annales De 
Zootechnie, 25, 95-110. http://dx.doi.org/10.1051/animres:19760110

Boler, D. D., Holmer, S. F., McKeith, F. K., VanOverbeke, D. L, Hilton, G. G., Delmore, R. J., ... Allen, D. M. (2009). Effects of feeding zilpaterol hydrochloride for twenty to forty days on carcass cutability and subprimal yield of calf-fed Holstein steers. Journal of Animal Science, 87, 3722-3729. http://dx.doi.org/10.2527/jas.2009-1830

Bores, Q. R., Baeza, R. J., Quintal, F. J., \& Canul, J. S. (2007). Composición corporal de corderos F1 de pelo cruzados con razas especializadas para producción de carne. I. Rendimiento de la canal. Memoria de la XLIII Reunión Nacional de Investigación Pecuaria, Sinaloa, México. p. 264.

Brand, T. S., Genis, M. P., Hoffman, L. C., Van de Vyver, W. F. J., Swart, R., \& Jordan, G. F. (2013). Effect of dietary energy and the inclusion of $\beta$-adrenergic agonist in the diet on the quality of feedlot lambs. South African Journal of Animal Science, 43(Issue 1, Supplement 5), S140-S145.

Buttery, P., Brameld, J., \& Dawson, J. (2000). Control and manipulation of hyperplasia and hypertrophy in muscle tissue. In: Ruminant Physiology: Digestion, Metabolism, Growth and Reproduction, P Cronjé (ed). Cabi International (pp. 237-254). http://dx.doi.org/10.1079/9780851994635.0237

Campo, A. M. M. Análisis sensorial de la carne. Consumidores (2005). In V. Cañeque \& C. Sañudo. (Eds), Estandarización de las metodologías para evaluar la calidad del producto (animal vivo, canal, carne y grasa) en los rumiantes. (pp. 409-422). Madrid, España. Monografías INIA, Serie ganadera No. 3.

Coleman, M. E., Ekeren, P. A., \& Smith, S. B. (1988). Lipid synthesis and adipocyte growth in tissue from sheep chronical fed a beta-adrenergic agent. Journal of Animal Science, 66, 372-378.

Dávila, R. J. L., Avendaño, R. L., Macías, C. U., Torrentera, O. G., Zamorano, G. L., Peña, R. A., \& González, R. H. (2013). Effects of zilpaterol hydrochloride and soybean oil supplementation on physicochemical and sensory characteristics of meat from hair lambs. Small Ruminant Research, 114(2-3), 253-257. http://dx.doi.org/10.1016/j.smallrumres.2013.07.009

Dikeman, M. E. (2003). Metabolic modifiers and genetics: Effects on carcass traits and meat quality. Brazilian Journal of Food Technology, 6(Special issue), 1-38.

Dikeman, M. E. (2007). Effect of metabolic modifiers on carcass traits and meat quality. Meat Science, 77 , 121-135. http://dx.doi.org/10.1016/j.meatsci.2007.04.011

Estrada, A. A., Barreras, S. A., Contreras, G., Obregon, J. F., Robles, E. J. C., Plascencia, A., \& Zinn, R. A. (2008). Influence of level of zilpaterol chlorydrate supplementation on growth performance and carcass characteristics of feedlot lambs. Small Ruminant Research, 80(1-3), 107-110. http://dx.doi.org/10.1016/j.smallrumres.2008.09.006

Estrada, R. J. C., Barreras, S. A., Contreras, G., Estrada, A. A., Obregón, J. F., Plascencia, A., \& Ríos, F. G. (2009). Effect of two B-adrenergic agonists on finishing performance and carcass characteristics in lamb fed all-concentrate diets. Journal of Applied Animal Research, 36(1), 33-36. http://dx.doi.org/10.1080/09712119.2009.9707025

Ferguson, S. (2001). Evolving concepts in G protein couple receptor endocytosis. The role in receptor desensitization and signaling. Pharmacological Review, 53, 1-24.

Ferreira, M., \& Bastos, M. L. (1994). Os agonosts $\beta_{2}$ na producao de carne. Frm Port, 87, 61-67.

García, E. (1981). Modificaciones al sistema de clasificación climático de Köppen para adaptarlo a las condiciones de la República Mexicana. México, D. F. Instituto de Geografía. UNAM.

Garnier, J. P. (2010). Análisis del mercado mundial de la carne de ovino. Eurocarne, 184, 115-122. Retrieved June 19, 2015, from http://www.eurocarne.com/daal?al=boletin:imagenes\&2=18409.pdf

Google Earth. (2013). US Dept. of State Geographer. Image Landsat. Data SIO, NOAA, U. S. Navy, NGA, GEBCO. Accessed Oct 31, 2013.

Hernández, C. L., Ramírez, B. J. E., Guerrero, L. M. J., Hernández, M. O., Crosby, G. M. M., \& Hernández, C. L. M. (2009). Effect of breeding on carcass and meat quality of Mexican lambs. Arquivo Brasileiro de Medicina Veterinária e Zootecnia, 61(2), 475-483. http://dx.doi.org/10.1590/S0102-09352009000200027

Hilton, G. G., Montgomery, J. L., Krehbiel, C. R., Yates, D. A., Hutcheson, J. P., Nichols, W. T., ... Miller, M. F. (2014). Effect of feeding zilpaterol hydrochloride with and without monensin and tylosin on carcass cutability and meat palatability of beef steers. Journal of Animal Science, 87(4), 1394-1406. 
http://dx.doi.org/10.2527/jas.2008-1170

Holmer, S. F., Fernández-Dueñas, D. M., Scramblin, S. M., Souza, C. M., Boler, D. D., McKeith, F. K., ... Yates, D. A. 2009. The effect of zilpaterol hydrochloride on meat quality of calf-fed Holstein steers. Journal of Animal Science, 87, 3730-3738. http://dx.doi.org/10.2527/jas.2009-1838

Honikel, K. O. (1998). Reference methods for the assessment of physical characteristics of meat. Meat Science, 49, 447-457. http://dx.doi.org/10.1016/S0309-1740(98)00034-5

Hope-Jones, M., Strydom, P. E., Frylinck, L., \& Webb, E. C. (2010). The efficiency of electrical stimulation to counteract the negative effects of $\beta$-agonists on meat tenderness of feedlot cattle. Meat Science, 86(3), 699-705. http://dx.doi.org/10.1016/j.meatsci.2010.06.008

Hopkins, D. L. (2005). The relationship between live animal score and carcass fat score in lambs. Wool Technology and Sheep breeding, 36(2-3), 87-90.

International Centre for Trade and Sustainable Development (ICTSD). (2008). Biocombustibles y crisis alimentaria: nuevas evidencias. Puentes, 9(4). Retrieved June 19, 2015, from http://www.ictsd.org/bridges-news/puentes/news/biocombustibles-y-crisis-alimentaria-nuevas-evidencias

Kim, Y. S., Lee, Y. B., \& Dalrymple, R. H. (1987). Effect of the repartitioning agent cimaterol on grow, carcass and skeletal muscle characteristics in lamb. Journal of Animal Science, 65, 1392-1399.

Koohmaraie, M. (1994). Muscle proteinases and meat ageing. Meat Science, 36, 93-104. http://dx.doi.org/10.1016/0309-1740(94)90036-1

Koohmaraie, M., Shackelford, S. D., \& Wheeler, T. L. (1996). Effects of beta-adrenergic agonist (L-644,969) and male sex condition on muscle growth and meat quality of callipygen lambs. Journal of Animal Science, 74, 70-79.

Kretchmar, D. H., Hathaway, M. R., Epley, R. J., \& Dayton. (1190). Alterations in postmortem degradation of myofibrillar protein in muscle of lambs fed a $\beta$-adrenergic agonist. Journal of Animal Science, 68, 1760-1772.

Leheska, J. M., Motgomery, J. L., Krehbiel, C. R., Yates, D. A., Hutcheson, J. P., Nichos, W. T., ... Miller, M. F. (2009). Dietary zilpaterol hydrochloride II. Carcass composition and meat palatability of beef cattle. Journal of Animal Science, 87, 1384-1393. http://dx.doi.org/10.2527/jas.2008-1168

Lepetit, J., \& Culioli, J. (1994). Mechanical properties of meat. Meat Science, 36, 203-237. http://dx.doi.org/10.1016/0309-1740(94)90042-6

Li, Y. Z., Christopherson, R. J., Li, B. T., \& Moibi, J. A. (2000). Effects of a beta-adrenergic agonist (L-644,969) on performance and carcass traits of growing lambs in cold environment. Canadian Journal of Animal Science, 80(4), 459-464. http://dx.doi.org/10.4141/A99-076

López, C. M. A., Ramírez, R. G., Aguilera, S. J. I., Plascencia, A., Rodríguez, H., Arechiga, C. F., ... Gutiérrez, B. H. (2011). Effect of two beta adrenergic agonists and feeding duration on feedlot performance and carcass characteristics of finishing lambs. Livestock Science, 138(1-3), 251-258. http://dx.doi.org/10.1016/j.livsci.2010.12.020

López, C. M. A., Ramírez, R. G., Aguilera, S. J., Aréchiga, C. F., Méndez, L. F., Rodríguez, H., \& Silva, J. M. (2010). Effect of ractopamine hydrochloride and zilpaterol hydrochloride on growth, diet digestibility, intake and carcass characteristics of feedlot lambs. Livestock Science, 131(1), 23-30. http://dx.doi.org/10.1016/j.livsci.2010.02.018

Macías, C. U., Álvarez, V. F. D., Rodríguez, G. J., Correa, C. A., Torrentera, O. N. G., Molina, R. L., \& Avendaño, R. L. (2010). Crecimiento y características de la canal en corderos Pelibuey puros y cruzados F1 con razas Dorper y Katahdin en confinamiento. Archivos de Medicina Veterinaria, 42(3), 147-154.

Mersmann, H. J. (1998). Overview of the effects of $\beta$-adrenergic receptor agonists on animal growth including mechanisms of action. Journal of Animal Science, 761, 160-172.

Mohammandi, M., Abazari, M., \& Nourozi, M. (2006). Effects of tow beta-adrenergic agonists on adipose tissue, plasma hormones and metabolites of moghani ewes. Small Ruminant Research, 63, 84-90. http://dx.doi.org/10.1016/j.smallrumres.2005.02.005

Moloney, A. P., \& Beermann, D. H. (1996). Mechanisms by which beta-adrenergic agonists alter grow and body composition in ruminants. In G. Enne, H. A. Kupier \& Valentini (Eds.), Residues of veterinary drugs and 
mycotoxin in animal production. New methods for risk assessment and residues control. Wagening Pers, The Netherlands.

Moloney, A. P., Allen, P., Ross, D. B., Olson, G., \& Convey, E. M. (1990). Growth, feed efficiency and carcass composition of finishing steers fed the beta-adrenergic agonist L-644.969. Journal of Animal Science, 68, 1269-1277.

Mondragón, A. J., Domínguez, V. I., Pinos, R. J. M., González, M., Bosques, J. L., Domínguez, A., \& Mejía, M. L. (2010). Effect of feed supplementation of zilpaterol hydrochloride on growth performance and carcass traits of finishing lambs. Acta Agriculturae Scand, Section A 60, 47-52. http://dx.doi.org/10.1080/09064701003605158

Morón, F. O. E., Zamorano, G. L., Ysunza, F., \& González, M. N. F. (2002). Efecto del clorhidrato de zilpaterol y la vitamina $\mathrm{D}_{3}$ sobre la calidad de la carne en novillas comerciales. Revista Cientifica FCV-LUZ, XII(6), 725-729.

Nourozi, M., Abazari, M., Raisianzadeh, M., Mohammadi, M., \& ZareShahne, A. (2008). Effect of terbutalina and metaproterenol (two beta-adrenergic agonists) on performance and carcass composition of culled $\begin{array}{lllll}\text { Moghni ewes. } & \text { Small Ruminant } & \text { Research, } & 74(1-3), & 77 .\end{array}$ http://dx.doi.org/10.1016/j.smallrumres.2007.03.009

Organización de la Naciones Unida para la Alimentación y la Agricultura (FAO). (2014). Perspectivas Alimentarias. Resumen de Mercados. Retrieved August 3, 2015, from http://www.fao.org/3a-i4137s.pdf

Organization for Economic Co-operation and Development/Food Agriculture Organization. (OECD/FAO). (2013). Agricultural Outlook 2013-2022 Highlights. Retrieved June 19, 2015, from http://www.agri-outlook.org/highlights-2013-EN.pdf

Partida, P. J. A., \& Martínez, R. L. (2010). Composición corporal de corderos Pelibuey en función de la concentración de la dieta y del peso de sacrifico. Veterinaria México, 41(3), 177-190.

Partida, P. J. A., Braña, V. D., \& Martínez, R. L. (2009). Desempeño productivo y propiedades de la canal en ovinos Pelibuey y sus cruzas con Suffolk o Dorset. Técnica Pecuaria en México, 47(3), 313-322.

Partida, P. J. A., Vázquez, S. E. T., Rubi, L. M. S., \& Méndez, M. D. (2012). Effect of sire on carcass traits and meat quality of Katahdin lambs. Journal of Food Research, 1(4), 141-159. http://dx.doi.org/10.5539/jfr.v1n4p141

Pla, Y. M. (2005). Capacidad de retención de agua. In: V. Cañeque \& C. Sañudo. (Eds). Estandarización de las metodologías para evaluar la calidad del producto (animal vivo, canal, carne y grasa) en los rumiantes. (pp. 243-250) Madrid, España. Monografías INIA, Serie Ganadera No. 3. p. 246.

Ramos, F., \& Silveira, M. I. N. (2002). Agonistas adrenérgicos $\beta-2$ e produçao animal: III Efeitos zootécnicos e qualidade da carne. Revista Portuguesa de Ciencias Veterinárias, 97(542), 51-62.

Ríos, F. G., Gómez, V. A., Pinos, R. J. M., García, L. J. C., Estrada, A. A., Hernández, B. J., \& Portillo, J. J. (2011). Effect of breed on performance and carcass characteristics of Mexican hair sheep. South African Journal of Science, 41(3), 275-279.

Romero, M. A. M. (2011). Efecto del clorhidrato de ractopamina en el comportamiento productiva y características de la carne de ovinos en finalización. (Unpublished doctoral dissertation) Colegio de Posgraduados, Texcoco, Estado de México. México.

Salinas, C. J., Domínguez, M. R., Díaz, M. R., Cruz, B. P., Montaño, G. M. F., \& Arzola, A. C. (2006). Effect of duration of zilpaterol hydrochloride treatment on carcass characteristics and weight gain grazing Pelibuey lambs. Journal of Applied Animal Research, 29, 25-28. http://dx.doi.org/10.1080/09712119.2006.9706564

Salinas, C., Ramírez, R. G., Domínguez, M., Palomo, C. R., \& López, A. V. H. (2004). Influence of zilpaterol hydrochloride on growth and carcass characteristics of Pelibuey lambs. Journal of Applied Animal Research, 26(1), 13-16. http://dx.doi.org/10.1080/09712119.2004.9706497

Samadi, S., Jois, M., Dunshea, F. R., \& Leury, B. J. (2013). The $\beta_{3}$-adrenergic agonist (BRL35135A) improves feed efficiency and decrease visceral but not subcutaneous fat in lambs. Small Ruminant Research, 109, 128-132. http://dx.doi.org/10.1016/j.smallrumres.2012.07.028

Sañudo, C., Sánchez, A., \& Alfonso, M. (1998). Small ruminant production system and factor affecting lamb meat quality. Meat Science, 49(Supplement 1), 383-390. 
SAS. SAS/STAT User's Guide. (Released 9.1.3) (2008). Cary NC, USA. SAS Inst. Inc.

Schroeder, A. L. (2004). The effect of Optaflexx ${ }^{\mathrm{TM}}$ on growth performance and carcass traits of steers and heifers. In: Proceedings of $19^{\text {th }}$ Annual South Nutrition and Management Conference, University of Arizona, Tucson, pp 65-81.

Secretaría de Agricultura, Ganadería, Desarrollo Rural, Pesca y Alimentación (SAGARPA). (2005). Estimación del consumo nacional aparente de carne de ovino 1990-2005. Retrieved August 27, 2015, from www.sagarpa.gob.mx/ganaderia//Estadisticas/Paginas/default.aspx Dgg/Cnovi.html

Servicio de Información y Estadística Agroalimentaria y Pesquera (SIAP). (2014). Resumen Nacional. Producción, precio, valor, animales sacrificados y peso. Retrieved August 21, 2015, from http://www.siap.gob.mx/resumen-nacional-pecuario/

Sillence, M. N. (2004). Technologies for the control of fat and lean deposition in livestock. Veterinary Journal, 167(3), 242-257. http://dx.doi.org/10.1016/j.tvj1.2003.10.020

Steel, R. G. D., \& Torrie, J. H. (1980). Principles and procedures of statistics: A biomedical approach. New York, USA: McGraw-Hill Book Co.

Sumano, L. H., Ocampo, C. L., \& Gutiérrez, O. L. (2002). Veterinaria México, 33(2), 137-159.

Vázquez, S. E. T., Partida, P. J. A., Rubio, L. M. S., \& Méndez, M. D. (2011). Comportamiento productivo y características de la canal en corderos provenientes de la cruza de ovejas Katahdin con machos de cuatro razas cárnicas especializadas. Revista Mexicana de Ciencias Pecuarias, 2(3), 247-258.

Vergara, H. (2005). Composición regional y tisular de la canal ovina. In: V. Cañeque \& C. Sañudo (Eds). Estandarización de las metodologías para evaluar la calidad del producto (animal vivo, canal, carne y grasa) en los rumiantes. (pp. 170-178). Madrid, España. Monografías INIA, Serie Ganadera No. 3.

Warris, P. D. (2003). Ciencia de la carne. Zaragoza, España. Acribia.

Warris, P. D., Brown, S. N., Rolp, T. P., \& Kestin, S. C. (1990). Interaction between the beta-adrenergic agonist salbutamol and genotype on meat quality pigs. Journal of Animal Science, 68, 3669-3676.

Wheeler, T. L., Shackelford, S. D., \& Koohmaraie, M. (1997). Standardizing collection and interpretation of Warner-Bratzler shear force and sensory tenderness data. Proceedings of Reciprocal Meat Conference, 50, 68-77.

Wulf, D. M., \& Wise, J. W. (1999). Measuring muscle color on beef carcass using the L*a*b* color space. Journal of Animal Science, 77, 2418-2427.

Yang, T. Y., \& McElligott, M. A. (1989). Multiple actions of $\beta$-Adrenergic agonists on skeletal muscle and adipose tissue. Biochemical Journal, 261, 1-10. http://dx.doi.org/10.1042/bj2610001

\section{Copyrights}

Copyright for this article is retained by the author(s), with first publication rights granted to the journal.

This is an open-access article distributed under the terms and conditions of the Creative Commons Attribution license (http://creativecommons.org/licenses/by/3.0/). 